\title{
Phytoprotection
}

\section{Strain Improvement in Biocontrol Fungi}

\section{László Hornok, Gábor Giczey et Zoltám Kerényi}

Volume 79, numéro 4, 1998

OECD Workshop - Sustainable Pest Management, Safe Utilization of New Organisms in Biological Control. Montréal, Québec, Canada. September 27-30, 1998.

Atelier de l'OCDE - Gestion durable des ennemis des cultures,

Utilisation sécuritaire de nouveaux organismes de lutte biologique.

Montréal, Québec, Canada. 27-30 Septembre 1998.

URI : https://id.erudit.org/iderudit/706172ar

DOI : https://doi.org/10.7202/706172ar

Aller au sommaire du numéro

Éditeur(s)

Société de protection des plantes du Québec (SPPQ)l

ISSN

0031-9511 (imprimé)

1710-1603 (numérique)

Découvrir la revue

Citer cet article

Hornok, L., Giczey, G. \& Kerényi, Z. (1998). Strain Improvement in Biocontrol Fungi. Phytoprotection, 79(4), 136-138. https://doi.org/10.7202/706172ar d'utilisation que vous pouvez consulter en ligne.

https://apropos.erudit.org/fr/usagers/politique-dutilisation/ 


\title{
Strain Improvement in Biocontrol Fungi
}

\author{
László Hornok, Gábor Giczey and Zoltán Kerényi
}

Agricultural University and Agricultural Biotechnology Center, Gödöllö, Hungary

\section{INTRODUCTION}

Antagonistic and hyperparasitic fungi could be our useful allies in integrated pest management technologies allowing us to reduce the amount of pesticides released into the environment. Ampelomyces quisqualis, Coniothyrium minitans, Peniophora gigantea, Pythium oligandrum, as well as several species of Gliocladium and Trichoderma are the most potent biocontrol agents efficient against either leaf or soil inhabiting plant pathogens. The antagonistic activity of these fungi is attributed to various mechanisms including antibiosis, parasitism, competition and induced resistance (Goldman et al., 1994). There are many examples of the successful experimental use of hyperparasitic fungi, their application on a commercial scale is, however, limited to a few cases.

\section{AIMS AND METHODS OF STRAIN IMPROVEMENT}

The main reason of the scarcity of the commercial use of biocontrol fungi is their lower efficiency and reliability compared to chemical fungicides. One of the means by which the evectiveness of biological control could be increased is the use of genetically improved antagonistic (hyperparasitic) fungi. The biocontrol value of a wild-type isolate can be enhanced by different methods like mutagenesis, protoplast fusion and transformation. Papavizas and Lewis (1983) selected UV-induced mutants from Trichoderma viride and some of the mutants proved to be more efficient than the original strain. Protoplast fusion was also attempted to produce superior biocontrol strains (Harman and Hayes, 1993). However, the efficiency of this procedure is hampered by the genetic incompatibility existing between the parental strains; postfusional unstability was also found both in intraspecific and interspecific hybrids (Stasz et al., 1989). Transformation seems to be the most powerful method to achieve an outstanding combination of the desirable traits in a single strain, because this technique precludes the introduction of unfavorable properties into the recipients.

\section{IMPROVEMENT OF BIOCONTROL EFFICACY BY USING BIOTECHNOLOGICAL METHODS}

Species of the genus Trichoderma are by far the most intensely studied organisms in this field of research. These fungi produce extracellular cell-wall degrading enzymes, including chitinases, cellulases, $\beta-1,3$-glucanases and proteases. The mycolytic activity of these enzymes has long been recognized as a major factor in the hyperparasitic mechanism exerted by Trichoderma (Elad et al., 1982).

Different strategies have been tried to increase the chitinase activity of one of the most potent biocontrol species, T. harzianum. Haran et al. (1993) introduced the chitinase gene of Serratia marcescens into the genome of $T$. harzianum under the control of the 
constitutive $35 \mathrm{~S}$ promoter and obtained two transformants which expressed higher levels of chitinase activity in the presence of glucose. However, when these transformants were grown on chitin, the transgenic strains expressed lower chitinase activity than the parental wild-type strain. The authors explained this phenomenon by cleavage of the heterologous enzyme by host proteases and the interference of the resulting protein fragments with host chitinases during the secretory process. Margolles-Clark et al. (1996) used a transformation construct that contained the coding region of the $42 \mathrm{kDa}$ endochitinase gene (ThEn-42) of T. harzianum under the control of the cellulase promoter, cbh1 from Trichoderma reesei and could achieve a ten-fold increase of the chitinase activity in most of the 20 transformants tested. This was an elegant approach to the chitinase overproduction under in vitro conditions, but the behavior of these transformants under natural conditions is difficult to predict, as their increased chitinase production was elicited by cellulaseinducing components (owing to the chb1 promoter) and no specific induction occurred in the presence of chitin, the real substrate of the overproduced enzyme.

In our laboratory, another evolutionary variant of the $42 \mathrm{kDa}$ endochitinase encoding genes, named Tham-ch was cloned by screening the genomic library of Trichoderma hamatum, strain Tam-61 with a PCR-amplified chitinase sequence from the same fungus (Giczey et al., 1998). A $3.5 \mathrm{~kb}$ genomic DNA fragment containing the coding region, as well as the $5^{\prime}$ and $3^{\prime}$ regulatory sequences was reintroduced into the host strain by PEG-mediated homologous transformation under selection pressure provided by hygromycin $B$. The integration and the stability of the transforming construct was demonstrated by Southern blotting in 10 transformants. The integration of the transforming vector was stable only in one copy and occurred through homologous recombination in 9 of 10 transformants, while random integration was detected in one transformant. All but one transformant expressed higher levels of chitinase activity in comparison to the wild type recipient strain; the maximum level of increase rose 5-fold. Duplicating the copy number of the entire endochitinase gene under its own regulatory sequences is especially suitable for improving the biocontrol capability of Trichoderma as the highly conserved 42-kDa endochitinase-encoding gene, present in all mycophagous species of Trichoderma (Fekete et al., 1996) has been shown to be specifically triggered in mycoparasitic interactions (Carsolio et al., 1994). Triggering occurs when a specific "mycoparasitic" protein complex binds to the promoter sequences of the gene and displaces the binding of a catabolite repressor protein (Lorito et al., 1996). The transformation strategy we used was thus based on the molecular regulation of the Trichoderma endochitinase gene and RNA-blot analysis confirmed the rationality of this decision: when fungal cell wall preparation was added as a sole carbon source, significantly higher levels of Tham-ch mRNA were detected in all the transformants compared to the wildtype recipient. Another advantage of the $42-k D a$ endochitinase gene is that its overexpression causes no adverse effects on the transformants as described for the first time by MargollesClark et al. (1996) in T. harzianum. The disadvantage of our method is, however, that a bacterial antibiotic resistance gene was introduced into the transformants, precluding thus their outdoor testing.

Genes encoding lytic enzymes others than chitinases has also been used for the genetic improvement of Trichoderma strains. Co-transformation of $T$. longibrachiatum with the hygromycin resistance gene and the eg/1 gene, encoding $\beta$-(1,4)-endoglucanase resulted in a significant increase of the extracellular endoglucanase activity (SánchezTorres et al. 1994). In a more recent study (Migheli et al., 1998) these transformants were found to show enhanced biocontrol activity against Pythium ultimum on cucumber. The biocontrol ability of $T$. harzianum has successfully been improved by increasing the copy number of a basic proteinase gene (Flores et al. 1997); in greenhouse tests 
these transformants proved to be superior in reducing Rhizoctonia infection of cotton.

\section{PERSPECTIVES OF THE GENETICALLY MODIFIED HYPERPARASITIC FUNGI}

In this review examples were listed to illustrate research focussed on engineering more efficient biocontrol fungi. Many genetically improved strains were produced but - to the best of our knowledge - none of them have yet been tested under natural conditions. The efforts to construct genetically modified biocontrol fungi seem to be monocentric, in fact they are restricted to members of the genus Trichoderma and genes encoding (myco)lytic enzymes have been the only targets of genetic manipulation.

When this is considered the following questions (and appropriate answers) could promote the matter of strain improvement in biocontrol fungi.

What biocontrol species, other than Trichoderma could be recommended for genetic engineering? What could be the main points of the selection; usefulness in biocontrol, easiness in laboratory handling or environmental safety?

What traits, others than mycolytic ability are worth of improving; secondary metabolites, adaptation ability, competitiveness, tolerance against biotic and abiotic stress factors?

The majority of biocontrol fungi produces secondary metabolites, that could account for their biocontrol activity, but may adversely affect non-target organisms in nature. Can we advise molecular biologists to improve secondary metabolite production in these fungi? Alternatively, can we advise them to produce disarmed strains, deprived of secondary metabolite production and improved in other biocontrol traits?
Should we encourage research to uncover the secondary metabolite profiles of lesser known biocontrol fungus species?

\section{ACKNOWLEDGEMENT}

Some experiments described in this paper was supported by a research grant from OTKA (F 023692).

\section{REFERENCES}

Carsolio C, Gutiérrez A, Jiménez B, Van Montagu M, Herrera-Estrella A (1994) Proc Natl Acad Sci USA 91: 10903-10907.

Elad Y, Chet I, Henis Y (1982) Can J Microbiol 28: 719-725.

Fekete C, Weszely T, Hornok L (1996) FEMS Microbiol Lett 145: 385-391.

Flores A, Chet I, Herrera-Estrella A (1997) Curr Gen 31: 30-37.

Giczey G, Kerényi Z, Dallmann G, Hornok L (1998) FEMS Microbiol Lett (in press)

Goldman GH, Hayes C, Harman GE (1994) Trends Biotechnol 12: 478-482.

Haran S, Schickler H, Pe'er S, Logemann S, Oppenheim A, Chet I (1993) Biol Control 3: 101-108.

Harman GE, Hayes CK (1993). The genetic nature and biocontrol ability of progeny from protoplast fusion in Trichoderma. In: Biotechnology in Plant Disease Control (Chet I, ed.), pp. 237-255. Wiley-Liss, New York.

Lorito M, Mach RL, Sposato P, Strauss J, Peterbauer CK, Kubicek CP (1996) Proc Natl Acad Sci USA 93: 14868-14872.

Margolles-Clark E, Harman GE, Pentillä M (1996) Appl Environ Microbiol 62: 21522155.

Migheli Q, Gonzáles-Candelas L, Dealessi L, Camponogara A, Ramón-Vidal D (1998) Phytopathology 88: 673-677.

Papavizas GC, Lewis JA (1983) Phytopathology 73: 407-411.

Sánchez-Torres P, González R, PérezGonzález JA, González-Gandelas, Ramón D (1994) Appl Microbiol Biotechnol 41: 440-446

Stasz TE, Harman GE, Gullino ML, (1989) Exp Mycol 13: 364-371. 